\title{
Vi har efterhånden fundet vores egne ben som forældre
}

\section{Forældreskab og sundhedspleje i spændingsfeltet mellem velfærdsstat og privatsfære}

\section{Helle Haslund ${ }^{1}$ \& Mette Bech Risør ${ }^{2}$}

\author{
${ }^{1}$ Aalborg University Hospital \\ hht@rn.dk \\ ${ }^{2}$ The Arctic University of Norway \\ mette.bech@uit.no
}

Haslund, Helle; Risør, Mette Bech (2018). ‘Vi har efterhånden fundet vores egne ben som forældre: Forældreskab og sundhedspleje i spændingsfeltet mellem velfærdsstat og privatsfære.' i Tidsskrift for Forskning i Sygdom og Samfund, nr. 29, 121146

Der er særligt gennem de sidste 50 år sket en intensivering af et bornecentreret forældreskab, som i stigende omfang er orienteret mod børns sundhed og udvikling, hvor brug af ekspertråd er centralt. Præmature børn befinder sig i en forhøjet risiko for komplikationer relateret til sundhed, trivsel og udvikling, og de er ved fødslen oftest med forældrene indlagt gennem en periode på en hospitalsafdeling med specialiseret biomedicinsk ekspertise. Sundhedspleje er en universel velfardsydelse som næsten alle forældre $i$ Danmark tager imod, hvor Sundhedsstyrelsens medicinsk videnskabeligt informerede anbefalinger angående børns sundhed og udvikling formidles som samtidig støtte og kontrol. Støtten består $i$ at vejlede og informere forældre, og kontrol udøves som en skærpet pligt til underretning ved forhold som sundhedsplejersken finder bekymrende. Brug af sundhedspleje indgår således som ekspertinstans i forældres liv med deres born. Dette studie tager afsæt $i$ et etnografisk feltarbejde i og omkring danske familier med præmature børn. Det følger familierne i bar- 
nets første år, og for enkelte hovedinformanter op til to et halvt år, og det ser på, hvordan forældreskab forhandles i forældres møde med velfærdsstat eksemplificeret gennem sundhedspleje og sundhedspleje-ekspertviden. Vi diskuterer i artiklen, hvordan sundhedsplejens råd tilpasses, omsættes eller forkastes af præmaturforældre, og hoilken indflydelse dette har på konstitueringen af forældreskab. Vi argumenterer for, at mange danske forældre til præmature børn benytter 'hverdags-modstand' (Scott 1989) som en strategi og en reaktion på ekspertråd med tilpasninger. Dette bliver en måde at agere i det felt, der konstituerer børns liv $i$ den danske velfardsstat.

Gradually, we know where we stand as parents: Parenting and health care visiting in the tension between welfare state and private sphere

Parenthood has particulary during the last 50 years become increasingly child-centered and oriented towards children's health, well-being and development, where the use of expert advice is central. Premature children have an increased risk for complications related to health, well-being and development and are at birth often admitted with their parents at specialized hospital wards working with specialized medical expert knowledge. Health visitors is a universal welfare service that almost all Danish parents use. Health visitors communicate the National Health Boards recommandations regarding children's health and development in home visits as both support and control. The support consists in guidance and information and control consists in an obligation to notify social services if there is reason to worry. The use of Health visitors and their expertise is integrated into Danish parents' life with their children. This study is based on an ethographic fieldwork in Danish families with premature children. Fieldwork was conducted through the first year of the child, and for some of the key informants up to 2.5 years. The study explores how parenthood is negotiated in parents' encounter with the Danish wellfare state exemplified through healthcare and healthcare-expert knowledge. We discuss in the article how health care advice is adapted, operationalized or rejected by parents to premature children, and how this influences the constitution of parenthood. We argue that a lot of Danish parents to premature children use 'everyday resistance' as a strategy and a reaction to expert advice. This is a way to navigate in the public controlled and regulated field, that consitutes childrens' life in the Danish wellfare state. 


\section{Indledning}

I denne artikel undersøges og diskuteres, hvordan forældreskab til det let eller moderat præmature barn etableres i krydsfeltet mellem forældres egne erfaringer og ekspertviden eksemplificeret gennem sundhedspleje. Vi diskuterer i artiklen, hvordan sundhedsplejens råd tilpasses, omsættes eller forkastes af forældre, og hvilken indflydelse dette har på konstitueringen af forældreskab. Vi argumenterer for, at mange danske forældre til præmature børn benytter 'hverdags-modstand' (Scott 1989) som en strategi og en reaktion på ekspertråd med tilpasninger som en måde at agere i det felt, der konstituerer børns sundhed i den danske velfærdsstat. Sundhedspleje er et eksempel på en veletableret offentlig velfærdsydelse, som næsten alle forældre i Danmark tager imod (Buus: 2001). Sundhedsplejen repræsenterer ikke alene statslig omsorg, men også statslig autoritet med en juridisk indskærpet pligt til at underrette kommunale myndigheder, hvis forhold i hjemmet hos familierne findes bekymrende i forhold til barnets ret til sundhed og trivsel (Serviceloven §153). Børns ret udtrykkes desuden i Forældreansvarsloven. Heraf fremgår, at forældreskab indebærer et ansvar for og en pligt til at sætte barnets tarv med udvikling og behov for omsorg og tryghed og sundhed først i forældrenes liv (Forældreansvarsloven: 2015).

Velfærdssystemer omkring børn som sundhedspleje, barselsorlov, børnepenge, vaccinationstilbud, helbredsundersøgelser og pasningsgaranti er samlet et udtryk for børnevelfærdens centrale placering i velfærdsstaten. Sundhedsplejersken er systemets repræsentant overfor familien og formidler Sundhedsstyrelsens vejledninger (Rasmussen og Samberg: 2012). Sundhedsplejersker yder således vejledning, individuel støtte og rådgivning til gravide, spæd- og småbørnsforældre gennem blandt andet: Funktionsundersøgelser og regelmæssig kontakt med spæd- og småbørnsfamilier, herunder stotte til familiedannelse og tilknytning mellem barn og forældre, samt støtte og udredning i relation til sundhedsmæssigt truede børn (Nielsen: 2012). Sundhedspleje er dermed en måde hvorigennem velfærdsstaten accentuerer opfølgning og monitorering overfor f.eks. netop forældre med præmature børn, fordi det præmature barn er i forhøjet risiko for sundhedsmæssige problemer (McGowan: 2011).

Ifølge den danske sociolog Oline Pedersen monitoreres og klassificeres børn via anbefalinger fra Sundhedsstyrelsen og gennem sundhedsplejen med sundhedsprofessionelle eller pædagogiske værktøjer - det sunde og normale over for det syge og afvigende (Pedersen: 2015, s 25, 192). Samtidig viser hun, at sundhedsplejen udøver normative stærke diskurser om forældrepraksis, hvori ligger normer, 
krav og værdier omkring det ideelle forældreskab, som bliver definerende for forældrenes forståelse af sig selv som forældre og for barnet (ibid.). Velfærdsstatens udøvelse af omsorg via sundhedsplejen er ét eksempel på den store betydning som børneopdragelse, børnepasning og forældreskab tillægges, hvor den sundhedsprofessionelle ekspert er sundhedsplejersken. Ifølge historikeren Bente Rosenbeck er eksperters rolle for forældreskab og børnepasning ikke ny, men hænger sammen med medikalisering og professionalisering af moderskab, graviditet og fødsel i Vesten siden slutningen af det 19. århundrede (Rosenbeck:1987). Der er i sociologisk, antropologisk og historisk litteratur en enighed om, at der særligt gennem de sidste 50 år er sket en intensivering af et børnecentreret forældreskab som et fænomen, der efterhånden har nået globale dimensioner. Det drejer sig om et forældreskab, som i stigende omfang er orienteret mod børns sundhed og udvikling (Faircloth et al: 2013; Furedi: 2002; Hays: 1996; Lee: 2007; Furedi og Bristow: 2009). I 1990 anfører den engelske professor i sociologi Nikolas Rose eksempelvis, at alle forældre er orienterede mod at være medlem af en konsensus normalitet, hvor de elsker deres børn og er engagerede i deres psykologiske velbefindende, deres intellektuelle udvikling og deres fysiske sundhed (Rose: 1990). Den engelske sociolog Frank Furedi viser efterfølgende i 2002 på baggrund af sin analyse af forældreskabet i England og USA, at det undergår en forandringsproces, og han argumenterer for, at der har udviklet sig en 'parenting culture' (Furedi i Faircloth: 2013, Furedi: 2002). Denne er karakteriseret ved 'intensive parenting', som er et begreb for en ny stadigt mere omfattende forældrepraksis som ikke kan udøves af forældre uden viden fra professionelle eksperter (Furedi: 2002). Tendensen mod et ideal omkring 'intensive parenting' er blevet bekræftet i en række forskellige studier, som har udforsket middelklasse-miljøer i USA, England, Australien og Canada (Hays: 1996; Faircloth: 2010; Furedi: 2002; Schmeid et al 2001; Wall 2001, Lupton: 2011, 2012). Brug af videnskab og de professionelle råd med henblik på maksimering af det enkelte individs præstationspotentiale gennem tilvejebringelse af de bedste betingelser for sundhed og udvikling er centralt i 'intensive parenting' ifølge den engelske antropolog Charlotte Faircloth fra Centre for Parenting Culture Studies ved University of Kent (Faircloth et al: 2013).

I forhold til forældre med præmature børn argumenterer vi for, at forældreskabet er placeret i krydsfeltet mellem professionel viden, ofte sundhedsfaglig, og samfundsmæssige idealer om 'parenting culture' i højere grad end andre måder at udøve forældreskab på pga. de særlige omstændigheder omkring præmaturitet. Præmature børn ${ }^{1}$ er en særlig gruppe, hvor der som nævnt typisk er en mere hyppig kontakt med sundhedsplejen sammenlignet med raske nyfødte. Det sær- 
lige sundhedsfaglige fokus på gruppen er begrundet gennem forskning. Denne viser, at børn som er født let eller moderat for tidligt (mindst 3 og maksimalt 8 uger før beregnet termin), har en forhøjet risiko for sundhedsmæssige, psykologiske og kognitive problemer ikke alene i spædbørnsperioden, men også senere i barndommen (McGowan: 2011; Cserjesi: 2012; Vrijlandt et al:2013). Præmaturitet er således en risikofaktor, der potentielt kan true sundhed og udvikling hos barnet. Dermed placeres forældrene i en særlig situation, som adskiller sig fra forældre til raske nyfødte, hvor den for tidlige fødsel af barnet er et brud på forventningen om det raske fuldbårne nyfødte barn. Et sådant brud med det normale raske aktiverer forældres refleksive processer, som tydeliggør idealer om sundhed, en normal udvikling og trivsel hos barnet (Haslund: 2014). Forestillinger og forventninger angående barnets udvikling og sundhed giver således bekymring relateret til præmaturitet. I dette studie ser vi derfor på forældre til let eller moderat præmature børn, hvor forældrene oplever at være udfordrede af præmaturitet som en følge af den ofte flere uger lange hospitalsindlæggelse ved barnets fødsel og i det efterfølgende hverdagsliv i hjemmet med et barn, der er i en forhøjet risiko for komplikationer med såvel sundhed, trivsel og udvikling (ibid).

Med udgangspunkt i forholdet mellem ønsket om professionel viden og forestillinger om forældreskab, er formålet med artiklen således at diskutere, hvordan forældreskab til det let eller moderat præmature barn etableres i krydsfeltet mellem forældres egne erfaringer og ekspertviden, eksemplificeret gennem sundhedspleje.

\section{Metode, sampling og materiale}

Studiet tager afsæt $\mathrm{i}$ et etnografisk feltarbejde i og omkring danske familier gennem det præmature barns første år, og for enkelte hovedinformanter gennem op til to et halvt år. Familierne blev rekrutteret blandt let og moderat præmature børn fra to neonatalafdelinger med tilhørende barselsafsnit på to større danske hospitaler, og de havde bopæl omkring to større provinsbyer. Forældrene blev spurgt om deltagelse af sygeplejersker, under indlæggelse, og hvis de gav tilladelse, så besøgte $\mathrm{HH}$ dem efterfølgende, mens de stadig var indlagt og informerede om studiets formål og metoder. Derefter blev der lavet skriftlige samtykkeerklæringer med begge forældre i de familier, som ønskede at deltage i studiet. Syv hovedinformantfamilier, hvor seks var førstegangsforældre og en var andengangs, var $\mathrm{HH}$ hjemme hos i alt 138 gange af en varighed på mellem 4 og 12 timer af 
gangen. Andengangsforældrene blev inkluderet for at nuancere materialet, med viden om hvordan præmaturerfaringer var i sammenligning med erfaringer fra et forløb med et barn født til termin. Informantforældrene deltog tilsammen i fem almindelige mødregrupper. I disse fem mødregrupper var der foruden forældre til 22 børn, som var født til tiden, også 2 børn, som var født præmaturt. Hovedinformantfamilierne bestod af samboende forældrepar, som boede i og omkring førnævnte to større danske provinsbyer i hus/lejlighed, både lejede og ejede. Uddannelsesmæssigt var der stor variation blandt forældrene, svingende fra fuldført folkeskole til kandidatgrad og en $\mathrm{PhD}$ studerende. En enkelt forælder var arbejdsløs, mens resten var studerende eller i beskæftigelse indenfor eks. håndværk, militær, ufaglært, undervisnings- og sundhedssektor.

Feltarbejdet bestod overvejende af deltagerobservation af hverdagslivet i hovedinformanternes hjem, hvor der var tale om forskellige niveauer af deltagelse og observation. Der var familier, hvor HH deltog i praktiske gøremål, som f.eks. at sidde med børn på skødet og skifte bleer, og der var familier, hvor samværet mere havde karakter af at, HH var gæst på uformelt besøg. Over tid udviklede feltroller og niveauer for deltagelse sig i de forskellige familier, fordi der skete en udvikling i relationen. HHs ophold som en fremmed i hjemmet blev således gradvist reduceret og ændret til at være en 'ven af huset'. HH deltog efterhånden i mange forskellige aktiviteter, som var en del af familielivet som eksempelvis morgenmad, aftensmad, lægebesøg, sundhedsplejerskebesøg, barnedåb, grill på terrassen, indkøb, buskørsel, gåture, babybio, se TV, i mødregruppe, se internetsider med børnetøj og legetøj, se billeder af barnet på IPhone, drikke te, snakke og være stille. De mange timers samtale med forældrene i forbindelse med disse aktiviteter var en central del af deltagelsen. Ved feltarbejdets start holdt $\mathrm{HH}$ orienterende møder med lederen af sundhedsplejen i de områder, hvor informanterne boede, og fik tilladelse til at sundhedsplejerskebesøg indgik i feltarbejdet med henblik på at undersøge betydningen af sundhedspleje i forældreskabet til let og moderat præmature børn. Ud over deltagerobservation hos hovedinformantfamilierne (herunder deltagelse i almindelige mødregrupper) lavede HH supplerende deltagerobservation i otte præmatur-forældregrupper etableret af sundhedsplejen som et særligt kommunalt tilbud til forældre til for tidligt fødte børn uanset graden af præmaturitet. Hver af disse grupper bestod af 12-15 forældrepar, og gruppeforløbet på seks samlinger afholdtes i et lokale, som sundhedsplejen havde fået stillet til rådighed. Tilstede var to sundhedsplejersker med kompetencer omkring præmature og deres familier. Her deltog $\mathrm{HH}$ i alt 30 gange fordelt på de otte grupper. Disse præmatur-forældregrupper gav mulighed for at få viden om ligheder 
og forskelle i forældrenes erfaringer for hele gruppen af præmature, dvs. både erfaringer fra forældre til et let eller moderat præmaturt barn (dette studies informanter) og til et ekstremt præmaturt barn med længere hospitalsindlæggelse og mere komplekse behandlingsforløb bag sig.

Feltarbejdet bestod således af deltagerobservation og uformelle samtaler, men også suppleret med fokusgruppeinterviews og semistrukturerede forskningsinterviews. Fokusgruppeinterviews blev lavet i en tillempet version i de fem almindelige mødregrupper, HH deltog i. Der var tale om et fokusgruppeinterview, hvor der blev drøftet et enkelt eller to spørgsmål af gangen, fordi mødrene havde svært ved en længerevarende koncentreret deltagelse, da de samtidigt skulle sørge for deres baby. Gennem et forløb over fem gange blev de samme spørgsmål drøftet i de fem mødregrupper. De fem mødregrupper bidrog på den måde hver med et helt fokusgruppeinterview, som blot var afviklet opdelt over fem gange. Gennem disse fokusgruppeinterviews, uformelle og semistrukturerede interviews blev der blandt andet spurgt til informanternes erfaringer med at modtage sundhedspleje, ligesom $\mathrm{HH}$ havde fokus på det $\mathrm{i}$ deltagerobservation i familierne. $\mathrm{HH}$ lavede $\mathrm{i}$ alt 22 semistrukturerede interviews med forældrepar. De syv hovedinformantfamilier blev interviewet fire måneder efter fødsel og igen 10 måneder efter fødsel. Desuden blev fire familier der både havde et præmaturt og et ikke præmaturt barn, rekrutteret til to tilsvarende interviews fra præmatur-forældregruppen, for at få mere viden om oplevelsen af forældreskabet til et præmaturt barn i sammenligning med forældreskab til et ikke præmaturt barn.

Der blev til alle deltagerobservationer lavet scratchnotes med efterfølgende mere fyldige feltnoter, interviews blev optaget og transskriberet og analyseret ud fra en tematisk indholdsanalyse inspireret af Braun og Clarke (Braun, Clarke: 2006). Gennem den analytiske proces bragte $\mathrm{HH}$ fundne temaer tilbage til informanterne og sidsteforfatter gennem dialog, hvilket bidrog afgørende til nuancering og udvikling af temaer. Materialet blev gennemlæst og diskuteret med vejleder og informanter, og blev derefter kodet initialt, hvorefter materialet igen blev gennemlæst med identificering af foreløbige temaer. Disse blev herefter gennemgået og tilpasset ud fra check af temaerne i relation til citater og til materialet som helhed. Endelig blev temaerne defineret klart med betydning og indhold (ibid).

Analysen af interviews og feltnoter om forældres erfaringer med sundhedspleje viste overordnet, hvordan forskellige former for ekspertise blev integreret eller forhandlet over tid i hverdagslivet med barnet i bestræbelsen på at optimere sundhed og udvikling. To temaer blev defineret. Det første tema var: Forældres forhandlinger om sundhedsplejens legitimitet. Dette tema handler om, hvordan græn- 
serne mellem det private og det offentlige bliver forhandlet, og det positionerer sundhedspleje i spændingsfeltet mellem personlig frihed og statens ansvar. Det andet tema, Ekspertise og evidens møder hverdagserfaring, omhandler, hvordan sundhedsfaglig ekspertise ikke er et tilstrækkeligt videns-grundlag i hverdagslivets praksis med barnet. Under dette tema fremkom undertemaet: Ekspertise redefineres over tid. Dette undertema handler om, hvordan forældrene over tid akkumulerer egen erfaring med eget barn.

I forlængelse af den tematiske analyse og for at forstå flere nuancer af materialet har vi været inspireret af begrebet 'hverdagsmodstand' (Scott 1989; Scott 1990). I det danske velfærdssamfund, som er forholdsvist egalitært og rummer en stor middelklasse med både indflydelse og midler, er det sjældent at befolkningen tyr til åben modstand som organiserede protester eller revolter for at ændre på en uretfærdig og undertrykkende samfundsorden. Derimod er der en veludviklet tradition for at lade sin stemme høre og en tro på individets ret til selvbestemmelse og medindflydelse som medlem af et demokratisk samfund, hvilket i sig selv kan føre til forskellige typer af modstand - enten egennyttige eller som udtryk for et samfundssegments holdninger og rettigheder. Antropologen James C. Scott har med afsæt i studier af bondesamfund flere steder i verden og især i Malaysia først og fremmest haft interesse for klasserelationer og magtforhold mellem dominerende grupper og underordnede/undertrykte/afhængige grupper. Grupper som f.eks. ikke har politisk legitimitet, borgerrettigheder eller mulighed for at ændre sin status (kastesystemet). Han ønsker dog generelt at vise, hvordan underordnede gruppers ofte flygtige politiske handlinger og adfærd, som kan være skjulte, omskrevne, metaforiske, anonyme mv., er forsøg på at indtage en strategisk position som ikke kompromitterer gruppen åbent, men dog stadig er modstand. Disse handlinger er vigtige for forståelsen af magtrelationer (Scott 1990). Scott viser i sine analyser således, at underordnede grupper bruger to forskellige slags modstandsstrategier, dvs. på den ene side 'public transcripts', som er den åbne synlige interaktion mellem de underordnede og den dominerende magt - f.eks. revolution. Dette viser dog ikke hele spektret af interaktioner rettet mod magtforhold ifølge Scott (Scott 1990), så på den anden side udøves der også 'hidden transcripts' eller hverdagsmodstand, som er de handlinger, der sker 'backstage' uden at blive set eller noteret som synlig modstand. De som udøver disse former for modstand accepterer måske autoriteten i det åbne rum, men under overfladen kritiserer de og stiller spørgsmål ved den overordnede magt. Der er langt fra malaysiske bønders situation til småbørnsforældre i Danmark, konteksten er en helt anden, og forældre har f.eks. både rettigheder og handlerum, som ikke gælder for Scott's 
informanter. En af hans pointer er dog, at hans analyse er en strukturel analyse af forhold mellem dominante og underordnede grupper, dvs., hvor der er lignende strukturelle forhold, f.eks. mellem stat og borger, vil det være sandsynligt at strategisk adfærd for den 'underordnede' indeholder 'hidden transcripts'. Ved at trække disse modstandsformer frem synliggøres det, at kritik af magt ikke alene kan forstås ved at se på offentlige udtryk, men at også 'backstage' handlinger indeholder modstand. Gennem analysen af forældreskab og deres tale, praksisser og reaktioner på velfærdsstatens interventioner, ser vi derfor på forskellige former for hverdagsmodstand, som udtrykkes som f.eks. 'anonymitet' (herunder at støtte sig til rygter/historier) , 'eufemismer' (omskrivninger som dækker over noget der har negativ værdi, og som ville udløse reaktioner, hvis det blev formuleret uden omskrivning), eller bare 'at beklage sig' generelt og 'surmule' (ibid.). Disse hverdagsformer bliver suppleret med mere kollektive diskursive former som f.eks. konsensus om holdninger og praksisser udledt af mødregrupper. Overordnet er disse modstandsformer kritiske overfor, hvordan velfærdsstaten implementerer sundhed i befolkningen, og vi ønsker at forstå mere om, hvordan dette styresystem udøves, og hvordan forældreskab både i opposition til og i accept af en sundhedsoptik formes gennem hverdagsmodstandens sociale processer.

\section{Forældres forhandlinger om sundhedsplejens legitimitet}

Samtlige familier, HH mødte, modtog sundhedsplejebesøg i hjemmene, og forældrene omtalte sundhedspleje som et velfærdsgode og en rettighed. Selvom sundhedspleje blev set som en del af en offentlig velfærd, så blev sundhedsplejersken ikke opfattet som institution og stat for informanterne, men snarere et menneske med en fagprofessionel viden, som de kunne relatere til.

Informanterne benyttede sig alle af tilbuddet om sundhedspleje, hvilket muligvis hænger sammen med ønsket om at få den nyeste ekspertviden og de seneste gode råd om børn og forældreskab hjem i stuen. Men også ren velopdragen velfærdsstatsrutine spiller ind - hvorfor sige nej til et tilbud, som alle bruger og som vel må være godt, når staten tilbyder det? Samtidig gav det at benytte sundhedspleje en mulighed for at kunne referere til sig selv som gode forældre, der er åbne for input til barnets bedste (Furedi: 2013, Faircloth: 2013, Lupton: 1999, Hays: 1996I). Vi vil dog argumentere for, at sundhedspleje befinder sig i et spændingsfelt 
mellem forældres selvbestemmelse og et velfærdsstatsligt ansvar for barnet. På trods af velfærdsstatslig opmærksomhed og regulerende adfærd, så er forbindelsen mellem statslige intentioner og borgernes opfattelse og praksis ikke nødvendigvis harmonisk.

Tobias' forældre, Mads og Camilla eksemplificerer det, som blev udtrykt af flere forældre. At selvom de modtog sundhedspleje, så havde forældrene forskellige opfattelser af sundhedsplejens rolle og mandat, men der var ikke eksplicitte dialoger herom mellem sundhedsplejersken og forældrene.

Fra feltnoterne:

"Tobias er knap halvandet år gammel, og jeg er hjemme hos Camilla. Mads er ikke hjemme $i$ dag. Da snakken falder på sundhedsplejersken, siger Camilla til mig: "Ja, altså sundhedsplejersken, Mads kunne simpelthen ikke li' hende. Hun skulle ikke være styrende på den måde, men kun komme med forslag, hvis vi selv bad hende om det. Mads siger, at det var ligesom om, at hun kom med en model for, hoad der var rigtigt, og det brod han sig ikke om. Det er jo os, der er forældrene. Og jeg kan godt lidt se, hvad han mener, men det generede ikke mig så meget, for hun var jo meget sød. Men Mads synes, at hun var for personlig, og at hun gik for tret på mig også omkring vores parforhold, og at hun ikke skulle blande sig $i$ det, som ikke direkte havde med Tobias at gøre".

I et tidligere interview havde Mads sagt, at det var ok at sundhedsplejersken kom og målte og vejede Tobias. Det var et udtryk for, hvad han mente var en sundhedsplejeopgave. Til gengæld havde han klart til Camilla givet udtryk for, hvad han mente ikke var det. Mads ønskede sundhedspleje, men forbeholdt sig, selvom han ikke protesterede åbent, retten til at definere en grænse omkring sin privatsfære, og han eksemplificerer dermed Roses pointe om, at der er et paradoks i forholdet mellem stat og familie i moderne stater. På den ene side har staten en forpligtelse til at begrænse sin rolle med respekt for autonomi og privatliv. På den anden side er der en statslig forpligtelse om at regulere økonomisk og socialt liv, så det producerer velstand og velfærd (Rose: 1992, Murphy: 2003, Järvinnen og Mik-Meyer: 2012).

For Mads var parforhold ikke noget, som direkte vedrørte Tobias, men sundhedsplejersken spurgte meget indgående til det flere gange og særligt ved et af besøgene, hvor både Mads og Camilla var tilstede sammen med sundhedsplejersken, Tobias og HH. Mads svarede her meget kort på disse spørgsmål. HH havde 
desuden ved tidligere sundhedsplejerskebesøg og efterfølgende samtaler med Camilla observeret, at Camilla udelukkende spurgte sundhedsplejersken om praktiske råd om amning, flaske og søvn og gav udtryk for overfor $\mathrm{HH}$, at sundhedsplejersken først og fremmest skulle holde øje med om Tobias tog nok på i vægt, fordi han var født for tidligt og ikke vejede så meget ved fødslen. Sundhedsplejersken forsøgte flere gange at samtale om, hvordan Camilla havde det som mor. De korte svar Camilla gav betød, at emnet blev forladt. Til HH gav hun udtryk for, at hun ikke brød sig om, at der skulle gøres et problem ud af, at Tobias var født for tidligt, for hun syntes selv, at det gik helt fint. At Mads og Camilla navigerede udenom det, som sundhedsplejersken tilsyneladende opfattede som sin opgave, fik betydning for den rolle sundhedsplejersken fik i familien.

Eksemplet med Mads og Camilla er med til at rejse nogle spørgsmål om sundhedsplejerske-ekspertise og mandat, altså hvordan forældrene opfatter hendes rolle og grænserne for hendes virke i familien, set fra en position hvor familien kan opfattes som en privatsfære. For Mads og Camilla var det et spørgsmål om, hvorvidt det var en overskridelse af private grænser og en uretmæssig indblanding, da sundhedsplejersken spurgte til parforhold og moderskabsfølelser. Set udefra rejser der sig også spørgsmålet om, hvorfor Mads og Camilla ikke fortalte sundhedsplejersken, at hun skulle blande sig udenom. Med afsæt i begrebet 'hverdagsmodstand' er det imidlertid oplagt at opfatte deres strategi som en måde at prøve at omformulere eller dreje opmærksomheden væk fra det, som er eller kan blive et konflikttema. Det centrale i hverdagsmodstand er, at der er tale om en modstand uden åben protest og organisering, hvor individet retter sig mod at opnå et personligt handlerum på en måde, som minimerer de risici, der ville være ved en åben konfrontation (Scott: 1989). Når Mads og Camilla ikke protesterede overfor sundhedsplejersken, men svarede kort og prøvede at lede opmærksomheden hen på barnets tarv, ser vi det som en form for eufemisme, en af 'hverdagsmodstandens' former, hvor et problem omskrives eller transformeres til et positivt emne for ikke at skabe konflikt. Det kom aldrig til en åben konfrontation med sundhedsplejersken som autoritet eller velfærdstatslig magtinstans, men Camilla og Mads fik afløb for deres meninger til HH. Mødregrupperne var også et fællesskab, som HH observerede, hvor sundhedspleje fra tid til anden blev drøftet kritisk mødrene imellem, særligt med hensyn til at sammenligne de råd de fik.

Camilla udtrykte med sætningen: "Det er jo os, der er forældrene", at forældreskabet for hende var et særligt domæne, hvor forældre har en ret til selvbestemmelse. For Mads var det at måle og veje barnet en legitim sundhedsplejerskeopgave, som var med til at berettige hendes tilstedeværelse i hjemmet, og de konkrete talvær- 
dier indtegnet på trivselskurven kunne be- eller afkræfte Mads direkte i sin forældreopgave. Netop måling af vægt og længde var for mange informanter vigtige handlinger, hvor udviklingen i tallene blev fulgt nøje. Flere mødre sms'ede eller ringede straks dagens nye mål for vægt og længde til faren, hvis han ikke var til stede - mens sundhedsplejersken stadig var på hjemmebesøg. Sundhedsplejerskerne understøttede gennemgående det betydningsfulde i at veje og måle barnet gennem umiddelbare anerkendende kommentarer omkring tilvæksten, hvilket peger på, at de var bevidste om den fremtrædende plads målingerne havde for forældre. Dagens målte værdier fremviste sundhedsplejersken altid på en normalfordelingskurve for vækst for børn på den medbragte bærbare computer med en forklaring om, hvor barnet befandt sig på vækstkurven. Da der kun fandtes en kurve udarbejdet til raske nyfødte børn, var det præmature barn dog oftest placeret meget lavt på eller decideret under den afmærkede kurve på trods af en tilfredsstillende tilvækst. Flere informanter efterlyste en særlig kurve tilpasset præmature børn, så de kunne få visualiseret barnets gode trivsel, uden at skulle sammenlignes med raske nyfødte børn. Når vejning og måling så konsekvent blev ekspliciteret ved kontakt med sundhedsplejersken, kan det være fordi, der her er tale om synlig og konkret handling, som har objektive resultater. Tilmed resultater som i forhold til barnets fysiske sundhed er en væsentlig indikator. At vejning og måling af længde var så centralt for informanterne hænger sammen med, at de præmature børn netop var født små, og at vækst derfor helt fra fødslen blev et særligt tema. Gennem ugelange hospitalsindlæggelser blev forældrene desuden introduceret til et biomedicinsk domæne, hvor sundhedsfaglige aktiviteter omkring barnet blev monitoreret og dokumenteret digitalt og på papirskemaer ved kuvøser og vugger. Selve præmaturiteten genererede en monitorerende praksis med fokus på tal og medicinske parametre. Almindelige forældreopgaver som bleskift og spisning blev også nøje overvåget med dokumentation af ble-indhold og antal minutter ved bryst eller antal $\mathrm{ml}$ mælk på flaske eller via sonde. Præmaturitet har dermed formentlig accentueret forældrenes fokus på talværdier og vækst. Den biomedicinske kontekst installerer en særlig usikkerhed hos forældrene efter udskrivelse, fordi forældrene under indlæggelsen var i en situation, hvor sundhedsprofessionel ekspertise var nødvendig for barnet. Efter udskrivelse er det sværere for forældrene at være tryg ved om egne vurderinger af barnets sundheds og trivsel er tilstrækkelige (Haslund: 2014).

Imidlertid finder Oline Pedersen også i sin undersøgelse af sundhedspleje til raske nyfødte børn en lignende praksis angående vægtkurver. Med begreberne kendsgerningernes magi og kurvernes sandhed, udtrykker hun, hvordan kurven over 
barnets vægt tildeles en sandhedsværdi, som rummer en vurdering af barnets samlede trivsel. Den meget tydelige brug af kurverne i sundhedsplejen befordrer en særlig optik ifølge Pedersen, hvor det målbare er i fokus og rummer nærmest hele svaret, på hvordan det går med barnet. Uagtet at der ikke sundhedsfagligt er belæg for at tillægge barnets vægt en så omfattende betydning (Pedersen: 2013). Bestræbelsen på at understrege kliniske, konkrete og antageligt mere objektive medicinsk informerede elementer i sundhedspleje var tydelig, når sundhedsplejerskerne konsekvent omtalte deres observation af motorik og reflekser for forældrene.

Vægt, længde og barnets motoriske udvikling var indeholdt i en åben observation og en tydelig konkret opgave. De udefinerbare parametre, som i høj grad omhandlede relationen mellem forældre og barn, relationen forældrene imellem og forældrenes oplevelse af egen identitet og rolle som mor og som far, var omfattet af sundhedsplejerskens opmærksomhed på familien, uden det ligeså direkte blev italesat under besøgene i hjemmene. Sundhedsplejersker forklarede ikke, hvordan fænomener som kontakt, samspil og tilknytning blev observeret, men kommentarer om eksempelvis en god kontakt og en flot opmærksomhed forekom hyppigt. En anden forælder, 'Stine', mor til Silas, opfattede imidlertid sundhedspleje som mere end at få Silas vejet og undersøgt. Om det at modtage sundhedspleje sagde hun til $\mathrm{HH}$ en dag i hjemmet over en kop te under et interview da Silas var 10 måneder:

"For mig der har det været godt, at hun OGSÅ tog sig af mig, for det hele har bare været rigtig svært. Hun har hjulpet med, at jeg fik sat nogle ord på også om min skuffelse. Mmm - ikke, jeg mener ikke over Silas, han er jo dejlig, men alle de drømme jeg havde om at skulle gå tur med barnevognen ned i Magasin og bare hygge gik jo helt i vasken. Jeg fik nok at gøre med at overleve og fá det hele til at hænge sammen bare sådan nogenlunde indeni mig. Så det at sundhedsplejersken hun var der for mig og lyttede, det var simpelthen noge,t som jeg kunne mærke, jeg havde brug for. Også fordi hun ligesom ikke selv var i klemme vel - men kom mere udefra og var faglig. For både min mand og min egen mor og min søster de var jo involverede og havde det selv svart med det. Så dem skånede jeg nok lidt, tror jeg".

Stine viser her, at hun anerkendte den psykiske støtte, som sundhedsplejersken havde ydet hende som mor i en vanskelig situation. Med andre ord var der forskellige opfattelser af, hvad der begrundede sundhedsplejerskens adgang og legitimitet i familierne. 
Sundhedsplejens adgang til familierne og legitimitet forhandles altså i et spændingsfelt mellem personlig frihed og statens ansvar, men indebærer også en praksis, der potentielt styrker forældreskabet. Vejning og måling af reflekser og motorisk udvikling handler om, at kendsgerningernes magi og kurvernes sandhed reproducerer sundhedsplejens legitimitet overfor forældre og samtidig reproducerer forældrene som kompetente forældre. Forældrene reflekterede ikke eksplicit over, at de var genstand for statslige reguleringer, hvilket peger på, at det for informanterne var en selvfølgelighed at indgå i relationer med velfærdsstatsprofessionelle som sundhedsplejersker. En selvfølgelighed som er informeret af den kulturelle accept af, at barnets sundhed med trivsel og vækst er et velfærdsstatsligt anliggende, og et ansvar forældre varetager $i$ et samarbejde med instanser som sundhedsplejen. Men blikket på 'hverdags-modstand' bidrager til forståelsen af, at der er grænser for adgang og for velfærdsstatens regulerende blik på børn og forældreskab - barnet er målet, men ikke parforholdet eller moderrollen - samt at reguleringen foregår med en bestemt optik - objektive parametre - som i sig selv installerer et primært blik rettet mod barnet og samtidig konstituerer forældreskabets kompetencer. I lyset af det stærke velfærdsstatslige fokus på børns sundhed og udvikling, der gør det meget svært at frasige sig tilbuddet om sundhedspleje uden derved at kompromittere ideen om det ansvarlige forældreskab, bliver 'hverdagsmodstand' desuden den mulighed, forældrene har for at reagere overfor sundhedsplejen.

\section{Ekspertise og evidens møder hverdagserfaring}

Flere var som Mads enten usikre på eller uenige i, hvilken ekspertise, sundhedsplejersken besad. Det var tydeligt, at sundhedsplejerskens ekspertstatus for informanterne hverken var givet på forhånd eller defineret alene gennem den formelle autorisation. Informanterne havde et klart ønske om en sundhedsplejerske med særlige kompetencer og erfaringer omkring præmature børn, så den tilbudte ekspertise kunne være rettet mod det præmature barns specifikke behov og situation. Sundhedsplejerskerne var formentlig klar over dette, for ved det første møde med forældrene præsenterede de deres faglige baggrund, uddannelse og erfaring med en understregning af eventuelle særlige kompetencer omkring præmature børn.

Mange forældre ignorerede alligevel eller efterkom ikke den givne ekspertanbefaling, og de udviklede i deres hverdagsliv med barnet kreative strategier for 
'hverdags-modstand', hvor de genetablerede egen frihed til at manøvrere forældreopgaven.

En af de arenaer, hvor sundhedsplejerskens givne råd og anbefalinger jævnligt var genstand for kritiske drøftelser, var i forældre/mødregrupperne. Forskelle i vejledning blev tydelige, når mødre sammenlignede forskellige sundhedsplejerskers anbefalinger om problemstillinger vedrørende eksempelvis søvn. Disse forskelle bidrog til informanternes opfattelse af, sundhedsplejerskens vejledning også bestod af subjektive erfaringsbaserede vurderinger, som ikke nødvendigvis var et udtryk for medicinsk naturvidenskabelig evidens, og det gav anledning til at måtte foretage sine egne vurderinger.

Selvom sundhedsplejersken altså tilsyneladende udtaler sig som ekspert, bliver hendes udsagn sammenlignet på mødregruppemøder, og møderne bliver et handlings- og forhandlingsrum for at ventilere og afprøve, hvordan forældrene selv tænker, hvilke erfaringer de har nu og fra før. Hvordan de skal forholde sig til uoverensstemmende råd, udøve hverdagsmodstand mod disse, etableres ofte i konsensus: stole på egen krop, være sin egen ekspert etc. Dette er en form for hverdagsmodstand som formes på et kollektivt plan, og som indeholder en form for accept af, at gøre som der bliver bedt om eller foreslået, samtidig med at man 'backstage' enes om, at gøre det, man nu selv synes, er rigtigt og bedst, dvs på en måde en 'creation of autonomous social space for assertion of dignity' (Scott 1989, Scott 1990). Også i konkrete møder med sundsplejersken dukker forældrenes egen ekspertise op som et mere 'praktisk ræsonnement', der rummer hverdagsliv og erfaringer, men som også indeholder anonymiseret modstand og en balance mellem forsøg på at efterleve/lytte til anbefalinger og alligevel gøre, som man synes bedst:

"Jeg er hjemme hos Nana. Holger er nu knap 7 måneder. Det er september, og vejret er i dag fint for årstiden med solskin fra en klar blå himmel dog med en lidt skarp og kølig vind i skyggen. Torsten er ikke hjemme, men er taget på biblioteket. Sundhedsplejersken ringer på og bliver budt ind af Nana. Holger er træt, så de bliver enige om at få vejningen overstået med det samme, så han måske kan komme ud at sove bagefter. På badevxrelset tager Nana tøjet af ham, og sundhedsplejersken roser hans opmærksomhed, kontakt og motorik. Hun fortæller Nana, hoad det især er, hun lægger mærke til, i forhold til den alder Holger har lige nu. Vxgten var flot, og Holger er smilende og dejlig rundkindet, noget sundhedsplejersken bemærker. Da vi igen kommer ud i køkkenet, er Torsten kommet hjem. Nana spørger, om han kan lægge Holger ud at sove, mens hun selv snakker fxrdig med sundhedsplejersken. Torsten tager Holger på armen, og Nana siger 
henvendt til sundhedsplejersken: "Åh, ja, der har jeg altså lige brug for at spørge dig og hore, hoad din vurdering er. Vi er nemlig altid uenige om, hoor meget tøj han skal have på. Torsten synes ikke, han skal have så meget på, som jeg gør, og det passer måske med, at jeg selv er sådan en frossenpind, og det er Torsten ikke. Men hoad er det rigtige at gøre? "Sundhedsplejersken forklarer, hvordan man ved at mærke barnet $i$ nakken, på hænderne samt op af armene kan vurdere om barnet fryser. Hun afslutter med at sige: "Men altså min erfaring er, at sådan en dag som $i$ dag, der vil jeg mene, at han skal have en trøje på. Ikke nogen heldragt måske, men en trøje i alle fald, fordi der er koldt i skyggen. "

Torsten kommenterer ikke hendes svar, men går med Holger på armen ud til barnevognen med trøjen $i$ den ene hånd. En tid efter sundhedsplejersken er gået, henter Torsten Holger ind igen, fordi han er vågnet. Han har ikke trøjen på. Jeg bemærker det, og Torsten siger: "Ja, sådan nogle ting synes jeg jo virkelig godt, vi både kan og skal finde ud af selv. Jeg kender min søn, og jeg ved hvad der er passende for ham. Det er ikke noget, hun kan bestemme, og jeg ved faktisk ikke, om det overhovedet er noget, som har med hendes faglighed at gøre, og jeg tror da heller ikke, at det er noget, man kan snakke om evidens indenfor".

Når Torsten undlader at give Holger trøje på, udtrykker han samtidig, at sundhedsplejersken ikke nødvendigvis er en ekspert på problemstillingen. Han udtrykker også, at en sådan problemstilling er omfattet af hans egen ekspertise som forælder, hvor hverdagserfaringerne med Holger gennem 7 måneder for ham vejer tungest. At han indirekte efterlyser 'evidens', kan ses som næsten 'false compliance' i forhold til sundhedsplejerskens faglighed, fordi han egentlig i højere grad stoler på egen erfaring. Holgers trøje en septemberdag er et eksempel på, at megen rådgivning handler om spørgsmål angående hverdagslivet med barnet, hvor en sådan evidens bestrides.

Ude-sovning i barnevogn er et særligt nordisk fænomen, og et eksempel på en anbefaling, der blev givet uden egentlig evidens, hvilket dog oftest blev sagt. Til gengæld blev opfordringen til at lade barnet sove udendørs i reglen efterfulgt af bemærkninger, som refererede til sundhedsplejerskens gode erfaringer med udesovning og nytteværdien af den friske luft. Med andre ord argumenterede sundhedsplejersken selv med erfaringsbaseret viden, når naturvidenskabelig evidens var fraværende. Sundhedsplejersken kvalificerede anbefalingen gennem brug af vendinger som: "Jeg har rigtig gode erfaringer med", "Hos andre familier i en lignende situation har jeg set". Sundhedsplejersken foretog derfor en form for kol- 
lektivisering af forældreerfaring akkumuleret over tid gennem hendes arbejde i mange familier.

I beslutningsprocesser i hverdagen indgår viden i et 'praktisk ræsonnement', som er influeret af både den samfundsmæssige og den intersubjektive kontekst. Ifølge Risør giver denne kontekst mening og betydning, og giver det 'praktiske ræsonnement' som videnspraksis et rationale og en legitimitet (Risør: 2002, 2003). Ligesom det er konteksten, som giver hverdagsviden en kompleksitet, "der rummer alle de situationer, tilfxldigheder, muligheder, historier og relationer, der kan få indflydelse på beslutninger handlinger og vurderinger ad hoc. Denne kompleksitet af det praktiske niveau, hvor umiddelbart subjektive erfaringer danner et partikulært men alligevel kulturelt determineret ståsted, danner basis for beslutningsprocesser og handlemåder i hverdagen" (Risør: 2002). I hverdagslivet var der et konstant flow af situationer, hvorigennem forældrene prøvede at imødekomme barnets behov med henblik på sundhed og udvikling. Er det nu, han er sulten? Når hun vågner nu og er ked af det, er det så fordi hun har ondt i maven, eller er det overstimulering og har med præmaturitet at gøre? Spørgsmål som disse var en betydningsfuld del af hverdagslivet, og hverdagen blev derfor en eksperimentel praksis for hverdagsbeslutninger. Det 'praktiske ræsonnement' involverede at evaluere konkrete situerede erfaringer med barnet, der blev justeret og tilpasset efterhånden (ibid). Men manglen på entydighed $\mathrm{i}$ forhold til den rigtige løsning var en kilde til stor usikkerhed hos mange forældre - på den ene side trak man således på eget praktisk ræsonnement, men på den anden side udløste dette også usikkerhed og i mange tilfælde havde man brug for sundhedsplejens autoritet og entydighed. Håbet om entydighed var gennemgående, og forældrene søgte aktivt at finde rigtige svar angående et præmaturt barn gennem internettet og bøger. At barnet var præmaturt begrænsede dog informanternes tillid til viden fra netværk uden præmaturerfaringer, fordi de var usikre på, om mere generel spædbørnsviden også gjaldt for det præmature barns særlige behov.

Forældrene efterspurgte derfor en særlig viden som specifikt omhandlede deres præmature barns sundhed og udvikling, fordi de ønskede at tilpasse deres forældrepraksis så den understøttede optimal udvikling og sundhed for barnet. Hvorvidt de generelle anbefalinger til raske nyfødte omfattede det præmature barn var en gentagen kilde til usikkerhed for hverdagsbeslutninger. Hverdagsbeslutninger blev ofte forsøgt understøttet af sundhedsplejersken, som komplementerede de generelle anbefalinger med sin erfaringsbaserede viden, der baserer sig på 'ekspertens' akkumulering af erfaringer. Til trods for dette synes forældrene fortsat at være usikre. Lave og Wenger pointerer, at kendskab til en generel regel 
på ingen måde sikrer, at den generalitet, den kan indebære, aktiveres under de specifikke omstændigheder, hvorunder den er relevant (Lave og Wenger: 1999). Denne pointe refererer i vores analyse til flere forhold, som er væsentlige for at forstå forældres usikkerhed omkring pleje og pasning af deres barn: Forældre ønsker råd og vejledning om deres præmature barn og får råd, som tager afsæt i mere generelle principper af sundhedsplejersken. I omsætningen af denne vejledning bliver forældre usikre på om principperne indfanger deres barns situation, og de tilpasser derfor løbende egen forældrepraksis, efter om det lykkes at få barnet til at spise eller sove eksempelvis. Når forældre vejledes ud fra sundhedsplejerskens erfaring, så vurderer forældrene vejledningen med det forbehold, at de selv kender deres eget barn bedst. Dette giver vægt til forældrenes erfaringsbaserede viden, men usikkerheden er fortsat tilstede grundet en mangel på entydighed.

Når sundhedsplejeekspertviden, uanset om den er baseret på forskningsevidens eller erfaring, skal omsættes i hverdagslivet af forældre, så foregår der derfor en omfattende forhandling. Ofte blev forandringer og tilpasninger begrundet $i$ konkrete forhold, som handlede om den specifikke situation med barnet. I denne kontekst fandt informanterne argumenter, som gjorde det til en ansvarlig forældrehandling at fravige rådet $i$ et eller andet omfang - en måde at udøve hverdagsmodstand på, dvs. delvist at sætte sig op imod ekspertens råd og følge egne betingelser og erfaringer. Et eksempel var sovning, hvor Sundhedsstyrelsen har udarbejdet kriterier for at sove sammen med sine børn i samme seng, hvor det blandt andet er påpeget, at børn skal ligge under egen dyne. Flere informanter erfarede dog, at barnet sov bedst, hvis der var en tæt kropskontakt til moren gennem natten, hvilket bragte dem i et dilemma i forhold til de gældende anbefalinger. Når det blev drøftet med sundhedsplejersken, tilkendegav mødrene oftest, at de prøvede på at efterleve reglerne, men at det var svært, når de var så udmattede og trængte til søvn. Sundhedsplejerskerne var i reglen her dels insisterende på indholdet i reglerne, men samtidigt anerkendende over for det svære $\mathrm{i}$ at finde overskud til at gøre det midt i nattens mulm og mørke. "Bare du prøver", var en pragmatisk konklusion $\mathrm{HH}$ flere gange hørte sundhedsplejersker anvende. Selvom kriterierne altså omgås, imødekommes omgåelsen til dels af sundhedsplejersken, der også forholder sig pragmatisk til konkrete situationer.

Victors mor fortalte mig om sine overvejelser i forhold til reglerne for samsovning:

"Det der med at ligge selv under egen dyne, det er jo meget godt, og jeg synes det er fint at være opmærksom på sådan noget med, om han fär det for varmt. Men 
han vågner altså bare for tit, hvis han ikke ligger op og ned af mig - og så fär jeg ikke sovet, og han gør heller ikke. Og det har vi begge brug for, hvis vi skal hænge sammen om dagen. Så ja, han ligger altså op af mig det meste af natten!"

Når ekspertise og hverdagserfaring operationaliseres til forældres praktiske hverdagsbeslutninger, så viser analyserne af interaktionen mellem forældre og sundhedspleje, at sundhedsplejerskens faglige ekspertise blev accepteret, kritiseret og anvendt i informanternes kontinuerlige forhandlingsproces. En forhandling, hvor andre former for ekspertise indgik, fra internettet, andre mødre i eksempelvis mødregruppe, familie, øvrigt netværk eller egen forældreerfaring. Selvom sundhedsplejerskeviden indgik i forældrenes beslutningsgrundlag, havde den ikke automatisk forrang, men blev medtænkt i forældrenes kontinuerlige situationsbestemte vurderinger. Med andre ord ser vi her flere strategier, som både er individuelle og kollektive for måder at yde kritik og modstand på og etablere sig et handlerum og et ståsted, hvorfra man kan agere. Vel at mærke både anonymt, tilsyneladende, indirekte og omskrevet - som typisk hverdagsmodstand, der i sidste instans 'leaves dominant symbolic structures intact' (Scott 1989).

\section{Ekspertise redefineres over tid}

Analyserne af hvordan sundhedsplejens ansvarsområder bestrides, og af måder hvorpå evidens og erfaringsbaseret viden forhandles på, giver begge anledning til forskellige former for hverdagsmodstand. De udvikler sig også over tid. I det fyldige datamateriale så vi, at informanternes forventning om entydige, konkrete svar og universelle løsninger efterhånden blev reduceret. Der var en voksende erkendelse af, at forældrenes situerede erfaringer fra hverdagslivet med eget barn var kvalificerende for valg og beslutninger, hvor de eksempelvis refererede til: "det er os, der kender ham bedst". I beslutningsprocesser foretog forældrene med tiden et mere gennemgående 'praktisk ræsonnement', som primært lagde vægt på situeret viden om barnet, og som blev hjulpet på vej af en social kontekst og konsensus (f.eks. mødregrupper) og en intersubjektiv erfaringsudveksling. Hverdagslivet rummede en kompleksitet, hvor det praktiske ræsonnement betingede, at informanterne medtænkte det konkrete hverdagsliv med eget barn. Forældrene tilpassede derfor anbefalinger om eksempelvis søvn som en form for 'operationalisering' af sundhedsplejerskens mere generelle vejledning til den specifikke situation, de befandt sig i. 
Laila, mor til Gustav, som havde vist sig mærket af præmaturitet angående gråd og søvn, konstaterede efter et år:

"Ja, helt ærligt. Hvem er det i grunden, der er eksperter? Nogen gange så kan jeg høre, at de nærmest bare gætter og kommer med en eller anden forklaring, som måske ikke engang passer sammen med det, andre har sagt til os. Nogen af de her ting, dem er der jo egentlig ikke nogen helt faste svar og løsninger på. $\mathrm{Nu}$ snakker jeg mest om det her med hans præmaturitet. En overgang ville jeg egentlig ringe til vores sundhedsplejerske, men Mikkel syntes godt, at vi kunne selv - og jeg kunne jo også godt se, at han havde ret. For hun kunne i grunden heller ikke vide, hoad den bedste løsning var, for hun kender jo ikke Gustav. Vi har efterhånden fundet vores egne ben som forældre, og jeg tror, vi er nået frem til, at vi ikke længere på samme måde spørger de såkaldte eksperter. For vi kan ligeså godt selv tage stilling til, hvad der virker, ved at afprove det og finde ud af om det passer til Gustav."

For Laila blev forståelsen af faglig ekspertise som noget entydigt undermineret over tid, og hun redefinerede derfor begrebet ekspertise, fordi hun nu selv kendte sin søn grundigt, så egne forældreerfaringer fik mere vægt som en situeret ekspertise. En sådan proces er gennemgående i materialet, hvor informanterne gennem de første tre-fire måneder ofte spurgte sundhedsplejersken om lov. Det drejede sig overvejende om beslutninger vedrørende ernæring, søvn eller stimulation. Informanterne betragtede hende i starten i høj grad som eksperten, ligesom de forventede klare svar med brugbare løsninger, og hun blev i reglen mødt med tillid. Det unikke, komplekse og detaljerede kendskab til barnet blev dog med tiden en væsentlig del af hverdagsræsonnementet og det at "finde sine egne ben som forældre" i konkurrence eller sameksistens med andre ekspertiser. En brugt argumentation var "det kan godt være, at det står sådan i bøgerne, men sådan er Felix altså ikke", hvorved konkret forældreviden om Felix kunne udfordre og endog afvise ekspertviden. Flere gav omtrent et år efter, ligesom Laila, udtryk for, at de nu mere havde "fundet deres egne ben som forældre", og at udefrakommende ekspertråd ikke betød så meget for dem nu, som de gjorde i starten. En af informanterne sagde om den første tid som mor:

"Det var dengang, hvor jeg følte, at jeg skulle spørge om lov. Når jeg tænker på det $i$ dag, efter to år, så virker det helt mærkeligt at tænke på, at jeg dengang 
ikke følte, jeg helt kunne tillade mig at bestemme selv - for hallo, det er jo mine børn!" (Dittes fremhævning).

En proces, hvor ekspertvejledning tilpasses hverdagen med det enkelte barn, kan ses som 'hverdags-modstand' mod indblanding. Direkte og åbenlys ansigt-tilansigt uenighed med afvisning af sundhedsplejerskens vejledning forekom ikke. F.eks. fravalgte Torsten at give sin uenighed til kende over for sundhedsplejersken. Muligvis ville han ikke over for Nana skabe en ubehagelig situation, men også når forældre var alene med sundhedsplejersken, fravalgte de den åbne konflikt. Torsten er dermed et eksempel på det, som var typisk, nemlig at modstand og tilpasning med forhandling af vejledning og ekspertise foregik ordløst gennem praksis. Tilmed i en ikke eksisterende dialog, hvor sundhedsplejersken som den ene part ikke fik mulighed for deltagelse, ligesom hun heller ikke vidste, at Torsten efterfølgende undlod at give Holger trøje på. For sundhedsplejersken har det en betydning, at modstand og tilpasninger var subtile og ofte skjulte for hende, fordi hun ikke fik mulighed for at indgå i en dialog om de modsætningsforhold, der kan være mellem en situeret hverdagspraksis og en mere generel vejledning. Hun fik ikke heller viden om, hvordan omsætningen af viden blev tilpasset hverdagslivet med barnet i processer med redefinering og fravalg, hvilket potentielt kunne kvalificere hendes vejledningspraksis over tid. Men balancen mellem magten og de underordnedes modstand er subtil og ofte ikke synlig, heraf 'hidden transcripts' (Scott 1990). Ikke alene kan åben modstand bringe dem, der yder modstand i en udsat eller ligefrem truet situation, det underminerer også modstandens potentiale og risikerer at bringe modstanderens position i fare. Når Torsten ikke ydede modstand åbent, mener vi, at han strategisk udøver 'hverdags-modstand' for ikke at risikere sin anseelse som kompetent far, og når sundhedsplejersken svarede på spørgsmålet om trøje den dag i september, så bidrog hun til konstruktion og rekonstruktion af en sundhedsplejefaglig ekspertposition - magtbalancen opretholdes, men med mulighed for handlingsrum.

Der hvor vi så modstand, så var informanternes rationale ofte, at de heldigvis selv bestemte når først sundhedsplejersken var ude af døren igen. Med en sporadisk kortvarig tilstedeværelse i hjemmet havde sundhedsplejersken ikke mulighed for kontrol, hvilket muliggjorde at informanterne uden dialog eller konfrontation kunne fravælge ekspertrådet. Forældrene havde med andre ord rig lejlighed til selv at afgøre, hvordan sundhedsfaglig ekspertise skulle vægtes overfor hverdagserfaringerne om barnets sundhed og udvikling. 
I analysen af modstand som 'hverdags-modstand' med tilpasninger og redefineringer i omsætningen af sundhedsplejeekspertviden, er det væsentligt at medtage Pedersens pointe om, at sundhedspleje med sundhedsplejeviden var normskabende og orienterede værdier i retning mod barnets sundhed og trivsel som et naturligt mål for alle forældre. Det blev tydeligt i de ræsonnementer forældrene foretog, at sundhedsplejerskens vejledning indgik i deres overvejelser som en del af beslutningsgrundlaget. Sundhedsplejeviden blev ikke ignoreret, men var fremtrædende som en form for ideal ramme for den gode praksis, også der hvor forældre fravalgte at følge givne råd. Så selvom forældrene gradvist tillagde egne forældreerfaringer mere vægt, var ekspertviden som sundhedspleje stadig tilstede i ræsonnementet.

\section{Konklusion}

Sundhedsplejens mangeårige rolle og funktion i velfærdsstaten peger på, at ideen om at anvende velfærdsstatslige sundhedsprofessionelle ekspertråd i forældrepraksis er blevet internaliseret og derfor optræder hos forældrene som et naturligt ønske og behov, som er normskabende. Oline Pedersen konkluderer i sin afhandling: Sundhedspleje - Studier af en normaliserende praksis, at borgerne lærer at ville det, de alligevel skal. Hun skriver, "at der sker en tilpasning til de gxldende institutionelle rammer og strukturer, en tilpasning, der ikke kun handler om indordning, men som også handler om en vxrdiorientring $i$ retning af, at synes om dem eller endog finde dem naturlige" (Pedersen: 2013).

Internaliserede normer er dog ikke ensbetydende med fuld accept, og til trods for sundhedsplejens status som velfærdsstatens omsorgsfunktion (men også kontrolfunktion) for børns sundhed og udvikling, bliver udøvelse af 'hverdagsmodstand' en anvendt strategi. Hermed etableres et mulighedsrum for situeret handling i det stærkt regulerede felt som danske børns sundhed er. Analysen har overordnet vist, hvordan ekspertise bliver operationaliseret over tid i hverdagslivet med det præmature barn i bestræbelsen på at optimere sundhed og udvikling. Forældre etableres i konteksten af præmaturitet med et stort fokus på at bruge viden for at tilgodese barnets særlige behov for udvikling og sundhed. Imidlertid er det $\mathrm{i}$ hverdagen med barnet ofte ikke muligt at opnå en entydighed, om hvilken viden der er bedst, og forældre oplever usikkerhed og opsøger forskellige former for viden. 
I præmatur-forældres omsætning af sundhedsplejeekspertviden udvikles et 'praktisk ræsonnement', der rummer hverdagsliv og erfaringer, men som også indeholder f.eks. anonymiseret modstand og 'false compliance'. I løbet af barnets første år tillægger forældrene gradvist egne forældreerfaringer stadig større vægt som en situeret ekspertise. På trods af at sundhedsplejerskens faglige ekspertise løbende blev accepteret, kritiseret og anvendt, så blev den aldrig åbenlyst anfægtet. Scott argumenterer for, at selvom modstand ikke er organiseret eller artikuleret åbent og kollektivt, så har den alligevel samlet set den konsekvens, at staten begrænses adgang til det, der var målet (Scott: 1987). Fordi forældrene udøver 'hverdags-modstand', er sundhedsplejerskens adgang til familierne og sammenhængen mellem givne vejledninger, advarsler og råd og forældres valg og handlinger overfor deres barn ikke givet.

Eksemplerne på hverdagsmodstand kan synes lidt langt fra den sammenhæng, begrebet er knyttet til hos Scott, hvor begrebet er udviklet via studier af magtrelationer mellem underordnede grupper (statsløse, statusløse, økonomisk afhængige, socialt undertrykte mv.) og disses dominerende magtgrupper. Det er da heller ikke meningen at postulere, at forældre i Danmark udgør en undertrykt gruppe, som er nødt til, strategisk, at benytte sig af 'hidden transcripts' for at positionere sig. Enten i forhold til en overmagt eller i forhold til gruppetilhørighed. Men det er alligevel interessant, hvordan den danske velfærdsstat, som måske ikke tænkes umiddelbart som et magtapparat der styrer almindelige processer som børneopdragelse og parforhold, alligevel har en regulerende rolle og iscenesætter hegemoniske relationer mellem stat og borger. Det er disse relationer som forældrene opponerer imod på forskellig vis, dog ofte med stor ambivalens, men uanset med tydelig 'hverdagsmodstand'. Flere af modstandsformerne er muligvis mere individuelle end kollektivt baserede, som de er i mange af Scotts eksempler - måske undtaget mødregrupperne som et rum hvor der forhandles konsensus om 'praktiske ræsonnementer' versus ekspertviden. Samtidig handler magten, som der reageres imod, især om 'status domination' (Scott 1990:198) - dvs. man udfordres på hvem og hvordan man bør være som forælder i dagens sundhedspolitiske fokus på ikke bare specifik sygdom, men også på barndom, opdragelse og parforhold. Dermed konstituerer man sig som forælder gennem måden at reagere på og gøre modstand på.

Som nævnt er forældrene dog ofte ambivalente og har behov for statens forlængede arm og rådgivning, bl.a. for at vise deres kompetence til at leve op til deres rolle som forælder/borger. Netop det at gøre brug af videnskab og professionelle råd med henblik på maksimering af det enkelte individs præstationspotentiale 
gennem tilvejebringelse af de bedste betingelser for sundhed og udvikling er centralt i begrebet 'intensive parenting' (Faircloth et al: 2013). På den ene side viser vi, at forældre til præmature børn higer efter evidens og professionelle råd, og på den måde bekræfter tendensen mod "intensive parenting". (Furedi: 2013, Faircloth: 2013, Lupton: 1999, Hays: 1996), men på den anden side etablerer de sin egen måde at være 'intensive' forældre på ved at navigere sig igennem både afvisning, omskrivning, accept og afprøvning af sundhedsplejens anvisninger. Dette er genkendelige strategier også for forældre til mature børn. Men for de med præmature børn er disse strategier og forældreskabet sat på spidsen, fordi det præmature refererer til en medicinsk tilstand, som umiddelbart kræver opmærksomhed og placerer forældrene i en i udgangspunktet usikker og sårbar situation. Fokus på sundhed og udvikling accentueres således overfor præmature børn, fordi de befinder sig i en risikogruppe angående sundhed og udvikling.

For mange danske forældre til præmature børn er 'hverdags-modstand' en strategi, der tilgodeser forældres behov for omsætning af sundhedsplejeekspertviden med tilpasninger, der til tider ikke følger givne anbefalinger. 'Hverdagsmodstand' er en måde at agere i det magtfelt, der omgiver forældreskab, hvor det ganske enkelt ikke er muligt at undlade at opfylde børns ret til sundhed og udvikling indenfor de rammer, som den danske velfærdsstat har defineret. Åben modstand kunne i yderste konsekvens potentielt aktivere velfærdsstatens magt til at fratage forældre autonomi og frihed i forhold til at træffe beslutninger om deres børn. At sundhedsplejen også havde en kontrolfunktion med mulighed for at lave kommunale underretninger, som kunne føre til interventioner, var en magt der ikke blev italesat på noget tidspunkt, men som formentlig har afgrænset informanternes mulighedsrum i forhold til at yde synlig modstand, fordi det er velfærdsstaten suverænt, som afgør om et barns krav på sundhed og trivsel kan opfyldes hos egne forældre, eller om barnets tarv bedst varetages som anbragt udenfor hjemmet. Dette magtforhold mellem stat og borger sætter begrænsninger for udøvelse af modstand og det mulighedsrum, hvor forældre kan træffe situerede hverdagsbeslutninger omkring deres præmature barn. Vi ser således, at forældre ikke åbent angriber sundhedsplejen som institution men gennem 'hverdags-modstand'. "They... find, a hundred ways around it, through it, and under it while leaving it standing" (Scott:1987). 


\section{Noter}

${ }^{1}$ Præmature børn defineres som børn, der er født mere end tre uger før beregnet fødselsdato (Howson et al: 2012)

\section{Referencer}

Braun V, Clarke V (2006): Using thematic analysis in psychology. Qualitative Research in Psychology; 2006: 3: 77-101 https://doi.org/10.1191/1478088706qp063oa

Cserjesi, R; Brackel,Koenraad Nja Van Braeckel; Timmerman, Marieke; Butcher, R, Phillipa; Kerstjens, M, Jorien; Reijneveld, A,Sijmen; Bouma, Anke; Bos,F,Arend; Geuze, H, Reint (2012): Patterns of functioning and predictive factors in children born moderately preterm or at term, Developmental Medicine and Child Neurology, published online 28.th may 2012.

Faircloth C; Hoffmann DM; Layne LL: (2013): Parenting in Global Perspective. Negotiating ideologies of kinship, self and politics. Routledge, Taylor \& Francus Group. London and New York. https://doi.org/10.4324/9780203103906

Forældreansvarsloven (2015: tilgået https://www.retsinformation.dk/pdfPrint. aspx?id=173278 10/8 $2018 \mathrm{kl} 15$

Furedi, F; Bristow J(2008): Licensed to hug. Civitas. Great Britain. Berforts Group Limited.

Haslund, H (2014): En antropologisk analyse af forældreskab efter præmaturitet - Moralske eksperimenter i en gråzone mellem sygdom og hverdagsliv. Ph.d. afhandling. Institut for Kultur og Samfund, Aarhus Universitet.

Hays, S (1996): The Cultural Contradictions of Motherhood. New Haven. London: Yale University Press

Howson, C.P; Kinney, M.V; Lawn, J.E. (eds) (2012): March of Dimes, PMNCH, Save the Children. WHO, Born Too Soon: The Global Action Report on Preterm Birth, World Health Organization, Geneva.

Järvinnen, M; Mik-Meyer, N (2012): At skabe en professionel. Hans Reitzels Forlag.

Lee, E (2007): Health Morality and Infant Feeding. British Mothers Experience of Formula Milk use in the early weeks. Sociology of Health an Illness. 29(7); 1077-1090. https://doi. org/10.1111/j.1467-9566.2007.01020.x

Lupton, D (2012): I am always on the lookout for what could be going wrong. Mothers Concepts and Experorahiences of Health and Illness in their Young Children. Sydney Health and Society Group. Working Paper no 1

Lupton, D (2011): »The best thing for the baby«: mothers' concepts and experiences related to promoting their infants health and development. Health, Risk and Society, 13(7-8), 637-651. https://doi.org/10.1080/13698575.2011.624179

McGowan JE; Alderdice FA; Holmes VA; Johnston L. (2011): Early childhood development of late-preterm infants: a systematic review. Pediatrics. 2011; 127(6):1111-1124. https:// doi.org/10.1542/peds.2010-2257 
Murphy, E (2003): Expertise and forms of knowledge in the government of families. Sociological Review, 51 (4). pp. 433-462. ISSN 0038-0261 https://doi.org/10.1111/j.1467954X.2003.00430.x

Nielsen, Westerlin Ch (2012): Sundhedsplejens lovmæssige grundlag. I: Rasmussen, J; Samberg, Vibeke (2012): Sundhedspleje. Et fag i forandring. Munksgaard. København

Pedersen, O (2013): Sundhedspleje - Studier af en normaliserende praksis, Ph.d. afhandling. Det Samfundsvidenskabelige Fakultet, Institut for Sociologi og Socialt arbejde. Aalborg Universitet

Rasmussen, J; Samberg, V (2012): Sundhedspleje. Et fag i forandring. Munksgaard. København.

Risør, MB (2003):Practical Reasoning as Everyday Knowledge. Health, Risk and Lifestyle in Health Promotion and the Everyday Life of Pregnant Smokers. In: Journal of the Danish Ethnographic Society (FOLK), vol 45. 2003.

Risør MB (2002): Den gyldne middelvej. Sundhedsfremme i hverdagen - en antropologisk analyse af gravide kvinders praktiske ræsonnement i relation til rygevaner. Ph.d. indleveret ved det Humanistiske Fakultet, Afdeling for Etnografi og Socialantropologi ved Aarhus Universitet. 2002

Rose, N(1990): Governing the soul. The shaping of the private self. Routledge. London.

Rose, N; Miller, P (1992): Political Power beyond the State: Problematics of Government I: The British Journal of Sociology, Vol. 43, No. 2. (Jun., 1992), pp.173-205 https://doi. org/10.2307/591464

Rosenbeck, B. (1987): Kvindekøn: Den moderne kvindeligheds historie 1880-1980. Gyldendal.

Schmeid et al. (2001): 'Contemporaty Breast-Feeding Policy and Practice Implications for Midwives'. Midwifery. 17(1): 44-54 https://doi.org/10.1054/midw.2000.0234

Scott, J C (1987): »Resistance without Protest and without Organization: Peasant Opposition to the Islamic Zaka and the Christian Tithe«. Comparative Studies in Society and History. Vol 29. No3 (Jul, 1987) pp 417-452. Cambridge Unversity Press

Scott, J C. (198): Everyday Forms of Resistance. Copenhagen Journal of Asian Studies 4:33-63. https://doi.org/10.22439/cjas.v4i1.1765

Scott, J C (1990): Domination and the Arts of Resistance. Hidden Transcripts. New Haven and London: Yale University Press.

Serviceloven: https://www.retsinformation.dk/forms/R0710.aspx?id=164215, tilgået d 1 2018

Vrijlandt E; Jorien M. Kerstjens; Eric J. Duiverman; Arend F. Bos; and Sijmen A; Reijneveld (2013): 'Moderately Preterm Children Have More Respiratory Problems during Their First 5 Years of Life Than Children Born Full Term'. American Journal of Respiratory and Critical Care Medicine, Vol. 187, No. 11 (2013), pp. 1234-1240. https://doi.org/10.1164/ rccm.201211-2070OC

Wall, G (2001): Moral Constructions of Motherhood in Breastfeeding Discourse. Gender and Society. 15(4): 592-610 https://doi.org/10.1177/089124301015004006 